\title{
Two new species of Ageniella Banks, 1912 (Hymenoptera: Pompilidae) from Brazil and updated keys
}

\author{
Márcia RAPOZA ${ }^{\circledR 1, *}$ \& Cecilia WAICHERT ${ }^{\bigotimes_{2}}$ \\ ${ }^{1}$ Universidade Vila Velha, Programa de Pós Graduação em Ecologia de Ecossistemas, Av. Comissário \\ José Dantas de Melo, 21 - Complexo Biopráticas, Boa Vista, Vila Velha ES - 29.102-920, Brazil. \\ ${ }^{2}$ Programa de Pós Graduação em Biologia Animal, Universidade Federal do Espírito Santo, Vitória, \\ ES, Brazil. \\ ${ }^{*}$ Corresponding author: marciarapoza@hotmail.com \\ 2Email: cwaichert@gmail.com \\ ${ }^{1}$ urn:1sid:zoobank.org:author:8BCDB41B-B5E2-4D82-AC4C-09BC35309007 \\ ${ }^{1}$ urn:lsid:zoobank.org:author:06771680-F022-4DC6-A0E5-20B467DC99FA
}

\begin{abstract}
Ageniella Banks, 1912 is a paraphyletic group exclusive to the Nearctic and Neotropical regions. The genus has a remarkable morphological diversity among species and strong sexual dimorphism, hampering taxonomic studies of it. Herein, we add two new species to the Neotropical fauna of Ageniella: A. caerulea sp. nov. belonging to the subgenus Ameragenia and A. ruschi sp. nov. belonging to the subgenus Priophanes; both species are described and illustrated. A brief discussion of subgeneric characters and an updated taxonomic key to the species of Ageniella known from Brazil are provided.
\end{abstract}

Keywords. Spider wasps, taxonomy, Ageniellini, Neotropical, Priophanes, Ameragenia.

Rapoza M. \& Waichert C. 2021. Two new species of Ageniella Banks, 1912 (Hymenoptera: Pompilidae) from Brazil and updated keys. European Journal of Taxonomy 787: 71-85.

https://doi.org/10.5852/ejt.2021.787.1615

\section{Introduction}

Spider wasps (Hymenoptera: Pompilidae) are insects that supply spiders to their immature as the only food source (Fernandez 2006). Usually, a single spider is paralyzed after being stung and placed in a nest cavity with a single egg (Rodriguez et al. 2016). The family is monophyletic and represented mainly by solitary species (Shimizu 1994; Pitts et al. 2006; Waichert et al. 2015).

Pompilidae Latreille, 1804 are found on all continents, except Antarctica, but their greatest diversity of species occurs in the tropical regions (Wasbauer 1995). There are close to 5000 described species in Pompilidae, distributed in about 230 genera (Aguiar et al. 2013) and five subfamilies (Waichert et al. 2015). One of the most diverse genera in Ageniellini (Pompilidae: Pepsinae) is Ageniella Banks, 1912. 
Ageniella is exclusive to the New World (Waichert et al. 2018). It was first described by Banks (1912) to house 17 species; currently there are about 200 names attributed to Ageniella, many of which are synonymous (Waichert et al. 2018). Ageniella is a paraphyletic genus (Shimizu et al. 2010; Waichert et al. 2019) that shows considerable structural diversity among species, including strong sexual dimorphism in some species (Evans 1997).

Currently, Ageniella has eight recognized subgenera, namely, Ageniella, Alasagenia Banks, 1944, Ameragenia Banks, 1945, Cyrtagenia Evans, 1973, Leucophrus Townes, 1951, Nemagenia Banks, 1944, Neotumagenia Fernández, 1998, and Priophanes Banks, 1944 (Waichert et al. 2018). Of these, Alasagenia, Cyrtagenia and Neotumagenia are endemic to the Neotropical region, which is the most diverse and least studied area of distribution of the genus. Waichert et al. (2018) revised the names occurring in Brazil, reporting 40 species of Ageniella and proposing a key to the subgenera and species of Ageniella. Here, we describe two new species of Ageniella from Brazil. The keys for Priophanes and Ameragenia are updated and photographs of the species are provided.

\section{Material and methods}

The studied specimens were loaned from the Brazilian collections at Instituto Nacional de Pesquisa da Amazonia (INPA), Manaus, Museu de Zoologia da Universidade de São Paulo (MZUSP), São Paulo, and Coleção Entomológica da Universidade Federal do Espírito Santo (UFES), Vitória.

\section{Abbreviations for morphological terms}

The species were described and named according to the International Zoological Nomenclature Code, prepared by the International Commission on Zoological Nomenclature (1999). The specimens had their external and internal structures (male genitalia) described according to the terms proposed by Wasbauer \& Kimsey (1985). Wing venation terminology follows Goulet \& Huber (1993).

$\mathrm{DF}=$ facial distance

LA3 = length of the third segment of the antenna

$\mathrm{LC}=$ maximum length of the clypeus

MID $=$ maximum interocular distance

OLO $=$ ocelocular length

$\mathrm{PDT}=$ transfacial distance

$\mathrm{POL}=$ post-cellular length

UID $=$ upper interocular distance

WA3 $=$ width of antennomere 3

$\mathrm{WC}=$ width of the clypeus, measured from the widest points

$1 \mathrm{M}=$ first discal cell

$2 \mathrm{M}=$ second discal cell

$1 \mathrm{Rs}=$ first submarginal cell

$2 \mathrm{R} 1=$ marginal cell

$2 \mathrm{Rs}=$ second submarginal cell

$3 \mathrm{Rs}=$ third submarginal cell

Taxonomic characters related to the male genitalia and hypopygium were examined after dissection. Dissected genitalia and hypopygia were soaked in a $10 \% \mathrm{KOH}$ solution for diaphanization of tissues and transferred into a microvial filled with glycerin for preservation. The microvial was pinned with the specimen for morphological analyses and illustration.

Type specimens were photographed using a Leica Z16 APO stereo microscope fitted with a camera adaptor coupled to a Leica DFC 295 video camera (Leica Microsystems, Switzerland, Germany). The 
Leica Application Suite ver. 3.6.0 software and Microsystems by Leica Limited (LAS) were used. Illumination was provided by a scaleable and modular LED illumination dome, as described in Kawada \& Buffington (2016). Helicon Focus (ver. 4.2.9; HeliconSoft, Dominica) combined stacks into a single image. The male genitalia were photographed using a Euromex microscope (Euromex Microscopen, The Netherlands) fitted with a HD-mini camera. Individual focal photographs were focus stacked in the Focus stacking online (https://focusstackingonline.com/) software using the Beta alignment method.

\section{Results}

We recognize two species that are reported here for the first time and included in the subgenera Ameragenia Banks and Priophanes Banks, as detailed below.

Class Insecta Linnaeus, 1758

Order Hymenoptera Linnaeus, 1758

Family Pompilidae Latreille, 1804

Genus Ageniella Banks, 1912

Subgenus Ameragenia Banks, 1945

Ameragenia Banks, 1946: 425. Type species: Ameragenia festina Banks, 1946 [Ageniella (Ameragenia) banksii Waichert, 2018].

Ageniella caerulea sp. nov. urn:Isid:zoobank.org:act:23CDBD6C-B833-4182-9109-61962BC8BB22

Figs. 1-2, 4

\section{Diagnosis}

Ageniella caerulea sp. nov. is the only South American species with blue integument and purple-greenish metallic reflections; the legs are castaneous with bluish reflections and the tarsi are light castaneous (Fig. 1A); the antenna is castaneous; the clypeus is trapezoidal, blue with greenish reflection; and the forewing is hyaline with two darkened bands. In females, the wing cells are darker than in males; the antennae, tibiae and fore tarsi are paler in males than in females (Fig. 1A, C).

\section{Etymology}

The specific epithet is Latin and refers to the blue color that stands out from that of the other spider wasps known from the Amazonian area.

\section{Material examined}

\section{Holotype}

BRAZIL • ${ }^{\text {; }}$ Amazonas, Manaus, Embrapa; 253'42.18" S, 5959'10.58" E; 11 Oct. 2012; E. Moerick and K. Schoeninger leg.; INPA.

\footnotetext{
Allotype

BRAZIL $\bullet$; ; same collection data as for holotype; INPA.

Paratypes

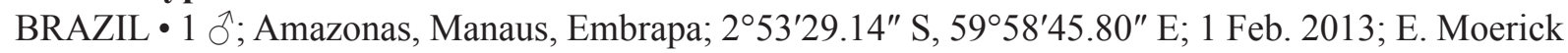
and K. Schoeninger leg.; INPA 1 \% ; same locality as for holotype; 18 Jan. 2013; E. Moerick and K. Schoeninger leg.; INPA.
} 


\section{Description}

Female (holotype)

Measurements. Body length $10.1 \mathrm{~mm}$. Forewing length $7.9 \mathrm{~mm}$; maximum wing width $2.8 \mathrm{~mm}$.

Coloration (Fig. 1). Head blue with purple-greenish reflections; antenna dark castaneous; clypeus blue with greenish reflections, apical margin dark castaneous; setae silver; mandible dark castaneous

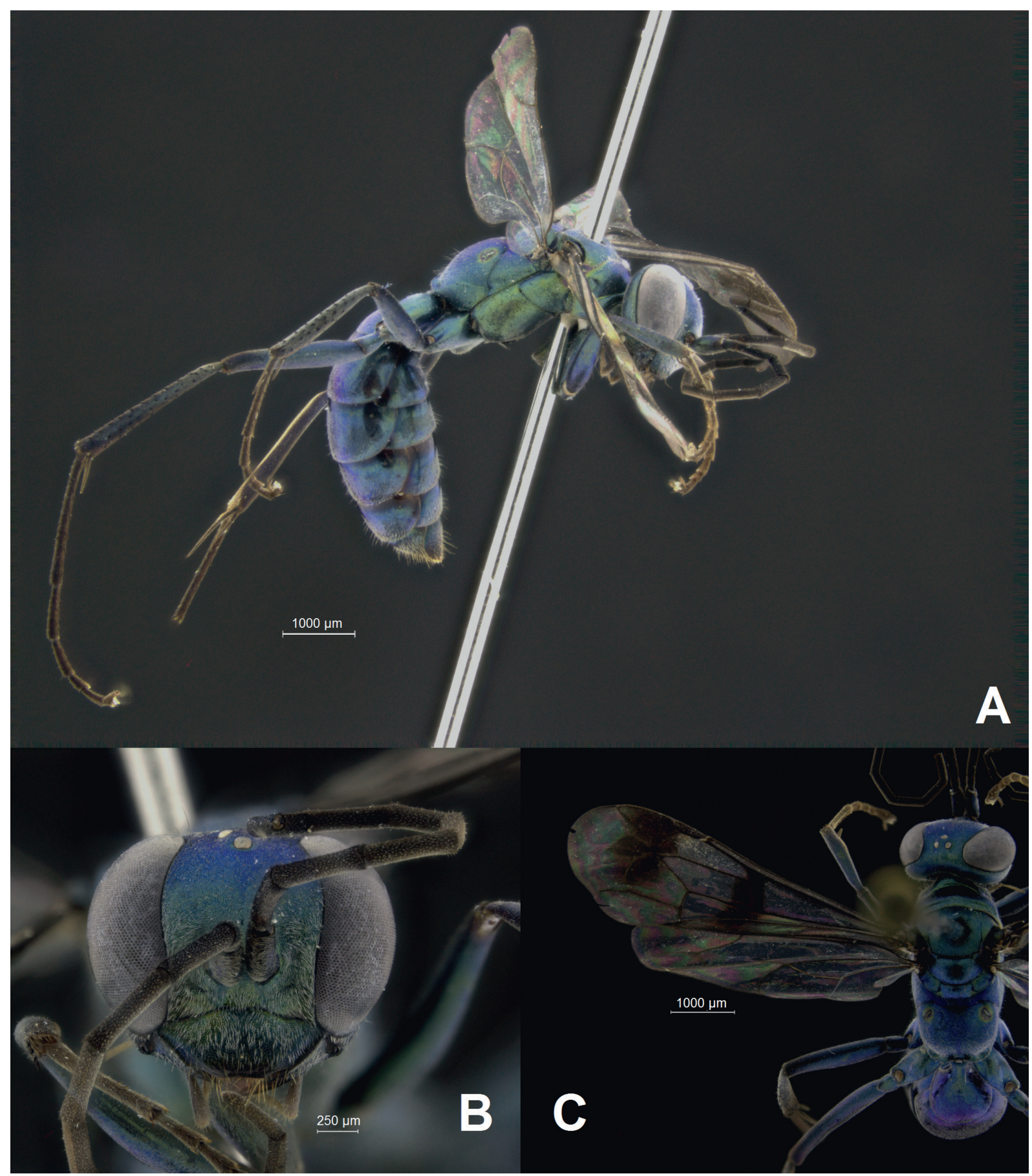

Fig. 1. Ageniella caerulea sp. nov.,, , holotype (INPA). A. Profile. B. Head, frontal view. C. Fore wing and dorsal view. 
with greenish reflections; maxillary setae castaneous; mesosoma blue with purple-greenish reflections; metasoma dark castaneous with blue-greenish reflections; wings hyaline; forewing with two darkened bands: inner band covering vein $\mathrm{M}$, basal portion of cells $\mathrm{R}, 2 \mathrm{Cu}$, distal portion of vein $1 \mathrm{Cu}$, and outer band covering cells $2 \mathrm{R} 1,3 \mathrm{Rs}, 2 \mathrm{Rs}$, distal portion of $2 \mathrm{M}$; forewing apex slightly darkened; veins castaneous.

HeAD (Fig. 1B). Wide; TFD $1.1 \times$ DF; MID 0.6 $\times$ DF. Punctation inconspicuous. Pubescence short. Ocelli in equilateral triangle; POL $0.8 \times$ OOL. Mandible narrow, wider at base, two sharp apical teeth. Clypeus trapezoidal, flat, anterior margin slightly curved; LC $0.2 \times$ WC. Antenna elongate; fourth segment $3.9 \times$ as long as wide; proportion of first four antennal segments 9:3:10:11; WA3 0,2 $\times$ LA3; LA3 $0.7 \times$ UID.

Mesosoma (Fig. 1A, C). Punctation inconspicuous. Pubescence sparse, thin; propodeum with long setae. Pronotum not elongated, width about $2.6 \times$ its length; pronotal collar short. Propodeum with slope slightly curved in profile. Forewing long, maximum width $0.35 \times$ its length; $2 \mathrm{R} 13.0 \times$ as long as its distance to apex; 3Rs $1.3 \times$ as long as 2 Rs; 2 Rs cell $2.0 \times$ as wide as long; 3Rs somewhat triangular; second recurrent vein curved, meeting 2 Rs at $2.0 \times$ distance from base to apex of cell. Fore, mid and hind tibiae with thick, short spines; hind tibiae with spines arranged in rows.

Metasoma. Polished, $1.31 \times$ as long as mesosoma; pygidium covered with short, erect pubescence.

Male (allotype)

Measurements. Body length $8.5 \mathrm{~mm}$. Forewing length $6.6 \mathrm{~mm}$; maximum wing width $2.0 \mathrm{~mm}$.

Coloration (Fig. 2A). Head blue with greenish metallic reflections; antenna pale castaneous; clypeus blue with greenish reflections; setae silver; mandible pale castaneous and blue with greenish metallic reflections; mesosoma purple-blue with greenish metallic reflections; metasoma castaneous with purpleblue-greenish metallic reflections; wings hyaline, darkened band covering cells 2Rs and 3Rs, cell 2M partially darkened, apex of wing slightly darkened; veins castaneous; leg castaneous with blue metallic reflections on coxae, trochanter and tibia; fore tibia, fore, mid and hind tarsi pale castaneous, distal portion of fore femur pale castaneous.

HEAD (Fig. 2B). Wide; TFD $1.3 \times$ DF; MID $0.5 \times$ DF; punctation inconspicuous. Ocelli in equilateral triangle; POL $0.8 \times$ OOL. Mandible narrow, base wider than apex. Clypeus trapezoidal, flat, median apical margin concave with lateral edges angulate; LC $0.2 \times \mathrm{WC}$; few long bristles present. Antenna elongate; fourth segment length $4.0 \times$ its width; ratio of first four antennal segments $9: 3: 1: 11$; WA3 $0.2 \times$ LA3; LA3 $0.8 \times$ UID.

Mesosoma (Fig. 2A). Punctation inconspicuous; pubescence scarce, thin. Propodeum with long, sparse erect setae. Pronotum not elongated, width about $4.3 \times$ its length; pronotal collar short. Propodeum with discrete punctation; posterior slope smooth. Forewing long, maximum width $0.3 \times$ its length; $2 \mathrm{R} 13.5 \times$ distance from its end to wing apex; 3 Rs $1.7 \times$ larger than $2 \mathrm{Rs}$; $2 \mathrm{Rs} 1.1 \times$ as wide as long; $3 \mathrm{Rs}$ triangular; second recurrent vein curved, meeting $2 \mathrm{Rs}$ at $1.7 \times$ distance from base to apex of cell. Tibia with few short spines.

Metasoma. Broken; polished; metasoma $1.17 \times$ as long as mesosoma.

Genitalia (Fig. 4A-D). Parapenial lobe split; lobe digitus-shaped, wide curved, total length $0.6 \times$ total genitalia length; apex truncate, curved; width constant along its length; dorsal lobe longer than ventral lobe, apex rounded inward, setae short, erect; ventral lobe spatulate, short, angulate, covered with thick bristles. Digitus wide, apex arched, inner margin truncate; total length $0.6 \times$ paramere total length. Aedeagus tongue-like, almost as long as parapenial lobe; apex truncate, apical median margin 
concave, gradually broadening apically. Paramere short, total length $0.7 \times$ total genitalia length; robust, constricted basally, two small projections on 0.3 and 0.6 portion from base; apex lanceolate; setae long, thick, sparse along the length, more abundant at apex. Subgenital plate trilobed; median lobe projected; lanceolate apically, setae thick, long at apex.

\section{Distribution}

Brazil (Amazonas).

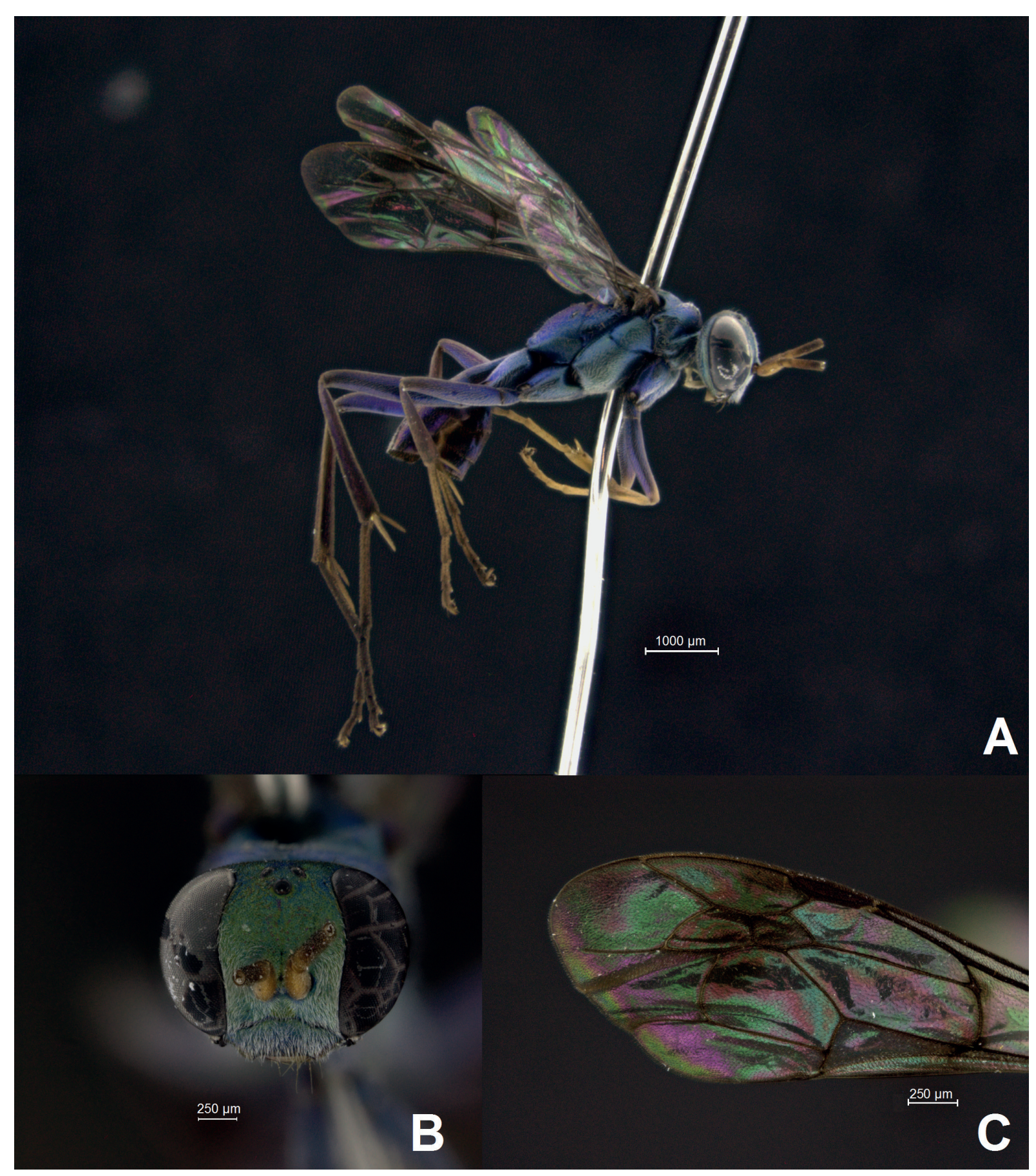

Fig. 2. Ageniella caerulea sp. nov., O̊, allotype (INPA). A. Profile. B. Head, frontal view. C. Fore wing. 


\section{Remarks}

The allotype has lost the antennal segment four onwards and the last three terga of the metasoma. This species has a unique blue-greenish color among the species of Ageniella. Usually the species of Ageniella have dark blue reflections, but they are rarely completely metallic blue and with greenish reflections as seen in this species. Ageniella dominguensis (Banks, 1944) has a blue color similar to that of $A$. caerulea sp. nov., but it differs from the latter by having a large body size, long setae covering the integument, and wings darkened without bands. Moreover, A. dominguensis is endemic to the Dominican Republic.

Subgenus Priophanes Banks, 1944

Priophanes Banks, 1944: 176. Type species: Priocnemis facetus Cresson, 1872, by original designation.

Ageniella ruschi sp. nov.

urn:1sid:zoobank.org:act:A54C1BAA-2AAC-44D6-BD29-A37DB75D6303

Fig. 3

\section{Diagnosis}

Ageniella ruschi sp. nov. is unique among the species of Ageniella by having golden scale-like setae basally and above the clypeus and the wings darkened with the apex white; the integument is dark castaneous (Fig. 3); and the clypeus is trapezoidal with the median apical margin polished and projected. The male of this species remains unknown.

\section{Etymology}

The species was named in honor of Augusto Ruschi (1915-1986), scientist, lawyer and teacher, known as the patron of ecology in Brazil, born in Santa Teresa, the type locality.

\section{Material examined}

\section{Holotype}

BRAZIL • O; Espírito Santo, Santa Teresa, Est. Biol. Sta. Lucia; 1958'16.7" S, 40³2'06.9" W; alt. 840 m; 6-9 Apr. 2001; C.O. Azevedo and Col. team leg.; Armadilha Malaise-bosque, pto 2; MZUSP.

\section{Paratypes}

BRAZIL • 1 क; Espírito Santo, Santa Teresa, Est. Biol. Sta. Lucia; 1958'37.3" S, 40³2'22.5" W; alt. 867 m; 6-9 Apr. 2001; C.O. Azevedo and Col. team leg.; Armadilha Malaise-bosque, pto 1; MZUSP

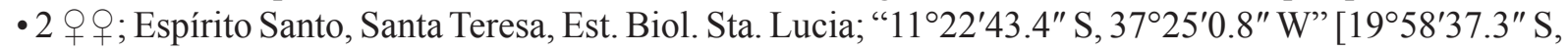
40³2'22.5" W]; alt. 750 m; 9-12 Apr. 2001; C.O. Azevedo and Col. team leg.; Armadilha Moericketrilha, pto 9; MZUSP - 1 क; Espírito Santo, Domingos Martins, Alto Biriricas; [20¹7'30.62" S, 40³5'57.73" W]; 8-22 Mar. 2019; B. Pissinati leg.; Malaise 3; UFES.

\section{Description}

Female (holotype)

Measurements. Body length $10.5 \mathrm{~mm}$. Forewing length $8.6 \mathrm{~mm}$; maximum wing width $2.5 \mathrm{~mm}$.

Coloration (Fig. 3A). Head dark castaneous; antenna, clypeus and mandibles dark castaneous, clypeus with scale-like golden pubescence; mesosoma and metasoma dark castaneous; wings darkened, apex whitish; veins castaneous; legs dark castaneous.

HEAD (Fig. 3B). Wide; TFD $1.18 \times$ DF; MID $0.55 \times$ DF; punctation inconspicuous. Pubescence short; pronotum, mesonotum, scutellum, metanotum, and anterior margin and slope of propodeum with scale- 
like pubescence. Ocelli in equilateral triangle; POL $0.9 \times$ OOL. Mandible narrow. Frons with declivity between antennal torulus and ocelli, covered with scale-like golden setae. Clypeus trapezoidal, anterior margin slightly constricted laterally, median apical margin projected, rounded, polished; LC $0.29 \times$ WC. Antenna elongate; fourth segment length $4.4 \times$ its width; ratio of first four antennal segments $9: 3: 10: 9$; WA3 $0.22 \times$ LA3; LA3 $0.9 \times$ UID.

Mesosoma (Figs. 3A). Punctation inconspicuous; pubescence scarce, thin. Propodeum with long, scarce erect setae. Pronotum elongated, width $6.3 \times$ length; pronotal collar short. Propodeum with scarce setae

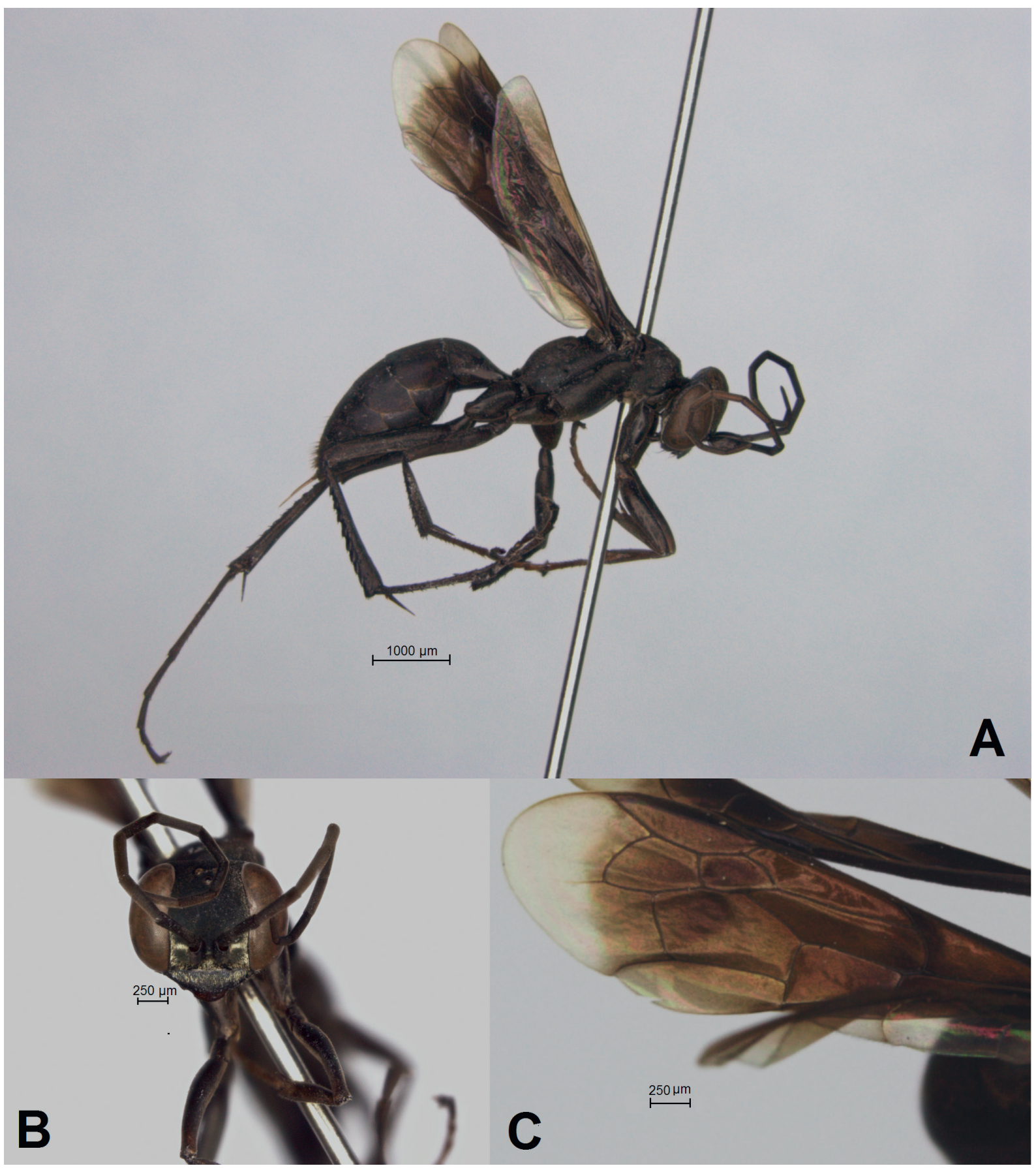

Fig. 3. Ageniella ruschi sp. nov.,, , holotype (UFES). A. Profile. B. Head, frontal view. C. Fore wing. 
and inconspicuous punctures; propodeum with slope, strongly arched. Forewing long, maximum width $0.3 \times$ length; $2 \mathrm{R} 12.5 \times$ distance from its end to wing apex; $3 \mathrm{Rs} 1.5 \times$ longer than $2 \mathrm{Rs}$; $2 \mathrm{Rs} 2.0 \times$ as wide as distance from its end to wing apex; 3 Rs somewhat triangular; second recurrent vein curved, meeting

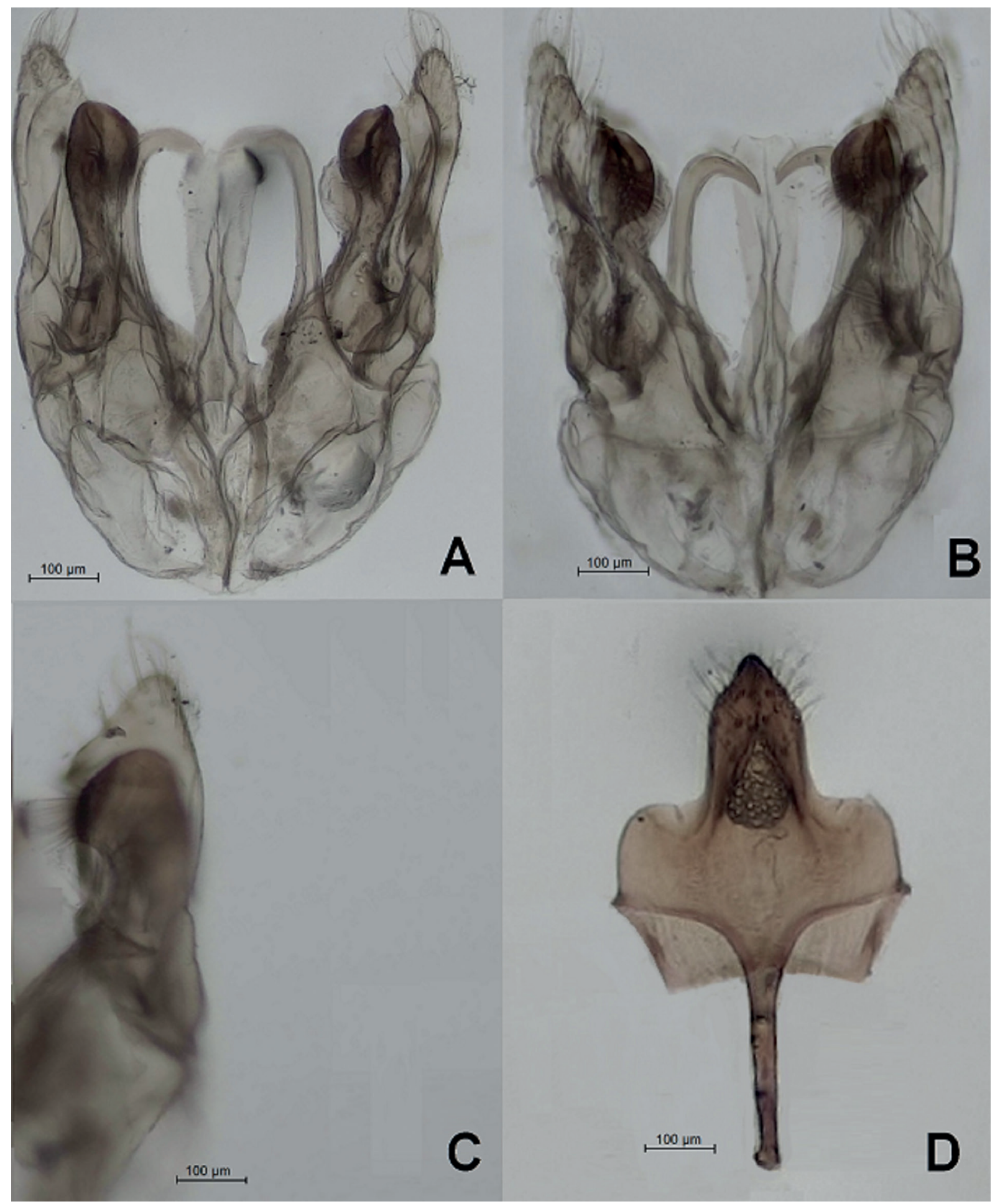

Fig. 4. Ageniella caerulea sp. nov., đ̂, allotype (INPA). A. Genitalia, ventral view. B. Genitalia, dorsal view. C. Paramere, lateral view. D. Hypopygium, frontal view. 
2Rs $1.7 \times$ distance from its end to wing apex. Fore and mid tibiae with spines large, thick, scale-like; hind tibia with spines large, thick, continuous, scale-like arranged in row.

Metasoma. Polished; pygidium covered with short, erect pubescence; metasoma $1.16 \times$ as long as mesosoma.

\section{Distribution}

Brazil (Espírito Santo).

\section{Remarks}

Ageniella ruschi sp. nov. is easily distinguished from other species of Ageniella distributed in Brazil by having the wing darkened with a whitish band on its apical fifth. Besides this unique wing pattern, the species has scale-like golden setae on the face and a frontal sulcus, only seen in few species of the genus.

\section{Modified key from Waichert et al. (2018) to the species of Ageniella (Ameragenia) from Brazil (females)}

1. Forewing maculated with darkened bands or distinct darkened spots 2

- Forewing without maculations of darkened bands or darkened spots, if darkened spot present, then very weak

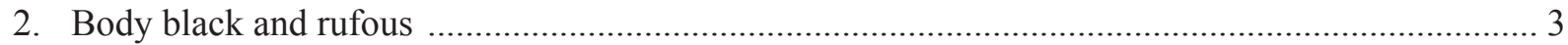

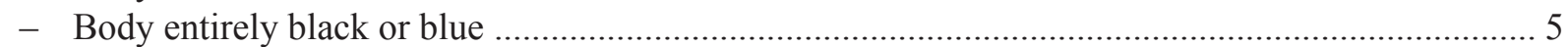

3. Clypeus large, apical median margin with two teeth; head and pronotum rufous; metasoma black with blue metallic reflections; forewing hyaline with two darkened bands

A. sanguinolenta (Smith, 1864)

- Clypeus various; head black (clypeus rufous in A. fabricii), pronotum various; metasoma various; forewing with or without darkened bands

4. Metasoma rufous; mesosoma and head black; forewings subhyaline with two darkened bands, the one on the basal vein narrow A. similaris (Banks, 1946)

- Metasoma black; mesosoma entirely or partially rufous, head black, clypeus rufous; forewing hyaline with two darkened bands, outer band incomplete

A. fabricii (Banks, 1944)

5. Forewing with darkened spots partially covering cell $2 \mathrm{M}$ and fully covering cell $2 \mathrm{Rs}$; cell $2 \mathrm{Rs} 0.69 \times$ as long as 3Rs; clypeus trapezoidal, its surface slightly arched; fore tibia pale castaneous

A. agitata (Smith, 1873)

- Forewing with one or two transversal darkened bands; cells 2Rs and 3Rs of different lengths; clypeus various; fore tibia black

6. Forewing with only one distinct darkened band (sometimes inconspicuous); silver setae covering integument on frons and distal portion of propodeum

- Forewing with two distinct darkened bands; if silver setae present, not densely covering frons and propodeum

7. Mid and hind femora, and inner side of fore femur pale castaneous; absence of blue reflections on hindwing veins and integument A. rustica (Fabricius, 1804)

- Fore, mid and hind femora black; blue reflections on hindwing veins and integument 
8. Integument black or blue without short and sparse golden pubescence; antennae various .............. 9

- Integument black with short and sparse golden pubescence, except propodeum, which has silver pubescence; antennomeres 1-8 light castaneous, segments 9-12 castaneous

A. banksii Waichert, 2018

9. Head and mesosoma blue with greenish reflections; clypeus blue with greenish reflections; antennae black A. caerulea sp. nov.

- Head and mesosoma never blue, without greenish reflections; clypeus different than blue; antennae various .....

10. Clypeus black; only antennomeres 7-10 yellowish; fore femur, tibia and tarsi black

A. citricornis (Fox, 1897)

- Clypeus pale castaneous; antennomeres entirely yellow; fore femur, tibia and tarsi black or dark castaneous and pale castaneous on the inner face

A. pretiosa (Banks, 1946)

11. Integument black with fore, mid and hind tibiae pale castaneous; forewing with a faint darkened spot on cells 2 Rs and $2 \mathrm{M}$.

- Integument black, mid and hind tibiae black; forewing various 13

12. Integument black with faint bluish reflections on head and metasoma; frons covered with silver scale-like setae from torulus to clypeus; anterior margin of clypeus trapezoidal; only fore tibia light castaneous

A. cleora (Banks, 1946)

- Integument black without bluish reflections on head and metasoma; frons without silver scalelike setae; anterior margin of clypeus rounded; fore, mid and hind tibiae with apical portion light castaneous

A. varipes (Fox, 1897)

13. Clypeus large, its surface arched, anterior margin with angulate median tooth

A. clypeata (Fox, 1897)

- Clypeus with surface truncate, anterior margin without tooth

14. Legs and antennae entirely black; cell $2 \mathrm{Rs}$ about $0.65 \times$ as long as $3 \mathrm{Rs}, \mathrm{tCu} 2$ vein curved, very arched, as well as vein $\mathrm{tCu} 1$

A. thione (Banks, 1946)

- Legs and antennae black, tibia with yellowish coloration; cells 2Rs and 3Rs of almost equal size ..

A. serrula (Fox, 1897)

\section{Modified key from Waichert et al. (2018) to the species of Ageniella (Priophanes) from Brazil (females)}

1. Forewing darkened, with whitish apex; head and body black; antennae black (Fig. 3)

A. ruschi sp. nov.

- Forewing hyaline or subhyaline, with or without darkened bands .............................................. 2

2. Forewing hyaline maculated, with two darkened bands ................................................................ 3

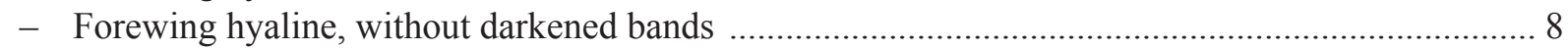

3. Integument with golden scale-like setae; face with depressions laterally to the antennal insertion ...

- Integument without golden scale-like setae; face without depressions laterally to the antennal insertions 
4. Clypeus large, its surface convex with a median angulate tooth on the anterior margin; metasoma black, covered with golden setae

- Clypeus large, its surface convex, with median anterior margin slighted projected, but without angulate tooth; metasoma orange-rufous, without golden setae

A. rufigaster (Banks, 1946)

5. Integument rufous; forewing subhyaline, with two faint bands; clypeus trapezoidal with an apical median tooth

- Integument various; forewing various; clypeus various

6. Antennomeres 1-7 orange-rufous (antennomere 7 of castaneous color as well); fore tibia, fore femur distally, mid and hind tarsi orange-rufous

A. rufitarsis (Fox, 1897)

- Antennomeres uniform in color; legs various

7. Head, legs and metasoma black with bluish reflections, mesosoma rufous; clypeus trapezoidal with anterior margin slightly trilobed; forewing with three wide darkened bands and two white bands

A. comes (Banks, 1946)

- Head, mesosoma and metasoma black with bluish reflections; clypeus trapezoidal with anterior margin slightly prolonged medially; forewing with two darkened bands

A. pallicornis (Banks, 1946)

8. Forewing darkened; metasoma with basal terga 1-4 rufous, apical terga black

A. basirufa (Fox, 1897)

- Forewing hyaline or subhyaline; metasoma uniform in color (basal terga black in A. otiosa) ........ 9

9. Metasoma black; dorsal integument covered without cuprum setae; forewing hyaline ................. 10

- Metasoma rufous, apical terga black; dorsal integument covered with cuprum setae; forewing subhyaline, tip broadly castaneous

A. otiosa (Banks, 1946)

10. Integument black without bluish-purple reflections; forewing darkened; clypeus trapezoidal, large, anterior margin slightly sinuous medially A. nigerrima (Fox, 1897)

- Integument black with faint bluish-purple reflections; forewing subhyaline; clypeus various .......11

11. Forewing with a faint darkened band partially covering cells $\mathrm{R}, 1 \mathrm{M}$ and $1 \mathrm{Cu}-2 \mathrm{Cu}$, and cells $2 \mathrm{R} 1$, 1 Rs-2Rs and $2 \mathrm{M}$, and vein $\mathrm{M}$ with small-faint spot; legs black; clypeus with anterior margin rounded

A. dolorosa (Banks, 1946)

- Forewing without faint darkened bands; mid and hind femora, tibiae and basitarsi rufous; clypeus truncate below

A. erythroptera (Banks, 1946)

\section{Discussion}

The present study adds two species to Ageniella, for the subgenera Ameragenia and Priophanes. The recognized species were included in the identification keys provided by Waichert et al. (2018), which has been improved and updated.

Waichert et al. (2018) included both, A. (Ameragenia) rustica (Fabricius) and A. (Ameragenia) zeteki (Banks), in the key for A. (Ameragenia) but listed them as A. (Alasagenia) in table 1. The authors discuss the presence of serrate legs and long-erect setae covering the body of these specimens, characters that overlap descriptions of subgenera Priophanes and Ameragenia, respectively, and also fit within species of $A$. (Alasagenia). However, Waichert et al. (2018) did not formally transfer the species to A. (Alasagenia) and we keep these two species as A. (Ameragenia) in the taxonomic key. Ageniella 
(Ameragenia) rustica and A. (Ameragenia) zeteki are probably a distinct lineage within Ageniella, but further data, such as nucleotide sequences, are needed for nomenclatural actions.

Although Ageniella is unquestionably paraphyletic (Shimizu et al. 2010; Waichert et al. 2015), we describe and place each species in a current subgenus for future studies and taxonomic delimitation. Ageniella caerulea sp. nov. is assigned to the subgenus Ameragenia, because it has the propodeum and the pronotum rounded in dorsal and profile views. The dorsal face of the hind tibia is spiny, but the spines are not similar to scales and the forewing is hyaline with dark bands. These features resemble those of other Neotropical species classified as A. (Ameragenia), such as A. fabricii (Banks).

Ageniella ruschi sp. nov. is assigned to the subgenus Priophanes due to the fact that it has a small to medium body size. The female has the hind tibia with scale-like spines, as known females in the subgenus. This species, however, differs from other species of the genus because of its darkened forewing with white tips.

Finally, this study represents a significant contribution to the systematics of a diverse group in a highly threatened biodiversity.

\section{Acknowledgments}

This study was financially supported by CNPq (\#435045/2018-0) and FAPES (\#85320846), granted to CW. We thank Drs W.D. Colombo, M.T. Tavares, and C.O. Azevedo, from Universidade Federal do Espírito Santo, for providing assistance and use of the Leica photograph system; and Dr Nesrine Akkari for valuable suggestions on the manuscript.

\section{References}

Aguiar A.P., Deans A.R., Engel M.S., Forshage M., Huber J.T., Jennings J.T., Johnson N.F., Lelej A.S., Longino J.T., Lohrmann V., Mikó I., Ohl M., Rasmussen C., Taeger A. \& Yu D.S.K. 2013. Order Hymenoptera Linnaeus, 1758. In: Zhang Z.Q. (ed.) Animal biodiversity: An outline of higher-level classification and survey of taxonomic richness. Zootaxa 3703 (1): 51-62.

https://doi.org/10.11646/zootaxa.3703.1.12

Banks N. 1912. Psammocharidae: Classification and descriptions. Journal of the New York Entomological Society 19: 219-237.

Banks N. 1944. Two new genera in Psammocharidae (Hymenoptera). Psyche 50 (3-4): 82.

Banks N. 1945. The Psammocharidae (spider-wasps) of northern South America, Part 1. Boletin de Entomologia Venezolana 4: 81-126.

Banks N. 1946. Studies of South American Psammocharidae. Part I. Bulletin of the Museum of Comparative Zoology 96: 311-525.

Cresson E.T. 1872. Hymenoptera Texana. Transactions of the American Entomological Society 4: 153292.

Evans H.E. 1973. Studies on neotropical Pompilidae (Hymenoptera) IX. The genera of Auplopodini. Psyche 80: 212-226. https://doi.org/10.1155/1973/25131

Evans H.E. 1997. Spider wasps of Colorado (Hymenoptera, Pompilidae): An annotated checklist. Great Basin Naturalist 3: 189-197

Fernández F. 1998. Nuevo subgênero y nueva espécie de avispa cazadora de arañas (Hymenoptera: Pompilidae) de Colombia. Caldasia 20: 1-4. 
Fernández F. 2006. Pompilidae. In: Fernandez F. \& Sharkey M.J. (eds) Introducción a los Hymenoptera de la Región Neotropical. Sociedad Colombiana de Entomología 894, Universidad Nacional de Colombia, Bogotá.

Goulet H. \& Huber J.T. 1993. Hymenoptera of the World: An Identification Guide to Families. Agriculture Canada Research Branch 668, Ottawa.

ICZN (International Commission on Zoological Nomenclature). 1999. International Code of Zoological Nomenclature. $4^{\text {th }}$ Edition 306, International Trust for Zoological Nomenclature, London.

Kawada R. \& Buffington M.L. 2016. A scalable and modular dome illumination system for scientific microphotography on a budget. PLOS ONE 11: e0153426. https://doi.org/10.1371/journal.pone.0153426

Latreille P.A. 1804. Histoire naturelle, générale et particulière des Crustacés et des Insectes. Vol. 7: Edited by C.S. Sonnini. F. Dufart, Paris.

Pitts J.P., Wasbauer M.S. \& von Dohlen C. 2006. Preliminary morphological analysis of relationships between the spider wasp subfamilies (Hymenoptera: Pompilidae): revisiting an old problem. Zoologica Scripta 35: 63-84.

Rodriguez J., Pitts J.P., Florez J.A., Bond J.E. \& von Dohlen C.D. 2016. Molecular phylogeny of Pompilinae (Hymenoptera: Pompilidae): Evidence for rapid diversification and host shifts in spider wasps. Molecular Phylogenetics and Evolution 94: 55-64.

Shimizu A. 1994. Phylogeny and classification of the family Pompilidae (Hymenoptera). Tokyo Metropolitan University Bulletin of Natural History 2: 1-142.

Shimizu A., Wasbauer M.S. \& Takami Y. 2010. Phylogeny and the evolution of nesting behaviour in the tribe Ageniellini (Insecta: Hymenoptera: Pompilidae). Zoological Journal of the Linnean Society 160: 88-117. https://doi.org/10.1111/j.1096-3642.2009.00592.x

Townes H.K. 1951. Subfamily Pepsinae (excluding Genus Pepsis Fabricius). In: Muesebeck C.F.W. Krombein K.V. \& Townes H.K. (eds) Hymenoptera of America North of Mexico. Synoptic Catalog. Agriculture Monograph No. 2: 1-1420. United States Department of Agriculture, Washington DC.

Waichert C., Rodriguez J., Wasbauer M.S., von Dohlen C.D. \& Pitts J.P. 2015. Molecular phylogeny and systematics of spider wasps (Hymenoptera: Pompilidae): redefining subfamily boundaries and the origin of the family. Zoological Journal of the Linnean Society 175: 271-287.

https://doi.org/10.1111/zoj.12272

Waichert C., Colombo W.D., von Dohlen C.D. \& Pitts J.P. 2018. Taxonomic contributions to Ageniella Banks, 1912 (Hymenoptera: Pompilidae) from Brazil. Zootaxa 4403 (1): 133-153.

https://doi.org/10.11646/zootaxa.4403.1.8

Waichert C., Wilson J.S., Pitts J.P. \& von Dohlen C.D. 2019. Phylogenetic species delimitation for the widespread spider wasp Ageniella accepta (Hymenoptera: Pompilidae), with new synonyms. Insect Systematics \& Evolution 62: 1-18.

Wasbauer M.S. 1995. Pompilidae. In: Hanson P.E. \& Gauld I.D. (eds) The Hymenoptera of Costa Rica: 522-539. Oxford University Press, Oxford.

Wasbauer M.S. \& Kimsey L.S. 1985. California spider wasps of the subfamily Pompilinae (Hymenoptera: Pompilidae). Bulletin of the California Insect Survey 26: 1-130. 
Manuscript received: 19 April 2021

Manuscript accepted: 15 November 2021

Published on: 4 January 2022

Topic editor: Nesrine Akkari

Desk editor: Eva-Maria Levermann

Printed versions of all papers are also deposited in the libraries of the institutes that are members of the EJT consortium: Muséum national d'histoire naturelle, Paris, France; Meise Botanic Garden, Belgium; Royal Museum for Central Africa, Tervuren, Belgium; Royal Belgian Institute of Natural Sciences, Brussels, Belgium; Natural History Museum of Denmark, Copenhagen, Denmark; Naturalis Biodiversity Center, Leiden, the Netherlands; Museo Nacional de Ciencias Naturales-CSIC, Madrid, Spain; Real Jardín Botánico de Madrid CSIC, Spain; Zoological Research Museum Alexander Koenig, Bonn, Germany; National Museum, Prague, Czech Republic. 